\title{
Community participation in forest resource management in Nepal
}

\author{
Keshav L. Maharjan \\ Graduate School for International Development and Cooperation, \\ Hiroshima University, Higashi-Hiroshima, Hiroshima 739-8529, \\ Japan
}

\section{Introduction}

Community participation in resource management essentially means sustainable use and management of natural resources by people, living in and around a region integrated ecologically, socially and culturally. Age-old traditional practices have often been neglected in this modernizing world. Yet, traditional practices that have been sustained over generations may provide insights for developing sustainable practices in the present scenario. While some traditional practices may be preserved as such, others might need some modifications depending upon their strengths and weaknesses in addressing the present/future problems. Building on traditional 
practices means less dependence on external assistance. If one realizes the potential of traditional practices in developing sustainable resource management packages, a detailed analysis of indigenous knowledge and socio-cultural capital need to be undertaken in varied environmental, social and economic conditions. This article focuses on traditional land use systems and impacts of development interventions, with special emphasis on forest resource use and management in Nepal.

\section{Farm-forest integration}

Traditional Nepalese farming is a location specific environment adaptive system. The farming system comprises crop, livestock and forest (inclusive of grasslands where ever they exist) as interconnected production sub-systems. Crop sub-system supplies fodder for livestock in the form of crop by-products. Livestock sub-system in turn provides draught power and manure required for sustenance of crop sub-system. Forests supply fodder, manure and a variety of other direct and indirect benefits needed for sustainable livelihood. Forests meet $78 \%$ of energy and $62 \%$ of fodder needs of the country. Almost all construction materials in rural area are forest products. Farm products are consumed locally or exchanged with various other goods/cash to secure livelihood (Figure 1). A balance in crop, livestock and forest production system has been maintained traditionally through community participation based on mutual aid, spontaneity, joint ownership and participatory decision making. Construction and maintenance of village canal system, wells, roads, community halls and organization of community festivals through the guthi system, capital accumulation through dhikur system (a kind of indigenous ROSCA (Rotating Saving and Credit Association) and regulation of forest resource uses through mana-pathi system are some examples of traditional community management in Nepal.

The traditional farm-forest integrated system is changing fast. A trend of production sub-systems getting more and more independent is apparent. This trend is often an outcome of the so called nation building/modernization programs and the changes in traditional value system. As people are unable to fulfill their demands from farming alone, they are turning to non-farm activities within or outside rural areas. In this new paradigm, peoples' needs are met from both farming 
and non-farming sectors (Figure 2). Sustainability of this new paradigm is also sought through community participation. However, since many activities in this paradigm are altogether new to local people, development interventions are frequently made in the name of community participation by government and NGOs.

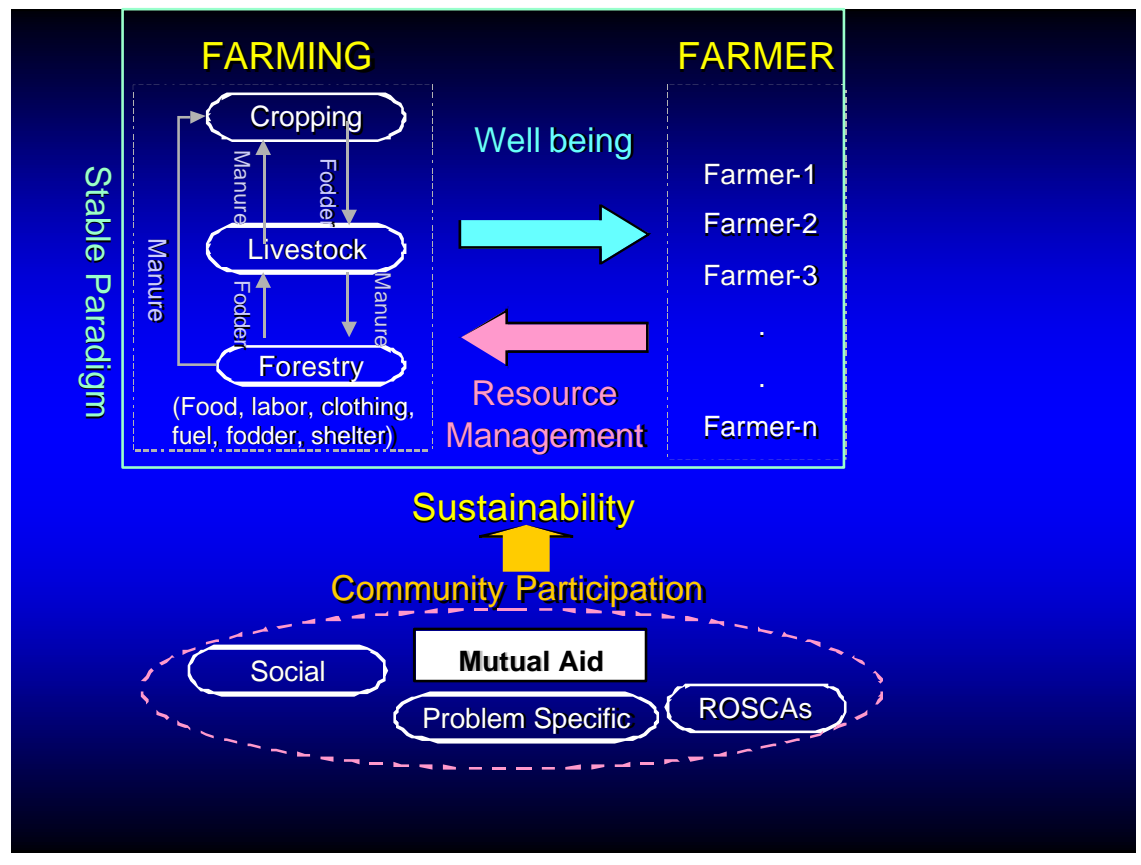

Figure 1: Traditional Location Specific Environment Adaptive Farming and Community Participation in Resource Management in Nepal.

\section{Development interventions and community participation}

Development interventions in Nepal have been implemented through civil society organization (CSO) such as cooperatives, associations (societies) and groups. Government has launched credit programs, particularly micro-credit programs. Users group programs advocate, facilitate and urge people to get empowered by forming groups to receive, use and bargain for government services/facilities. Forestry users group, irrigation users group, drinking water users group, rural road users group and mothers group are now quite 
common in Nepal. Forestry users group have become very popular in hilly regions. Many users groups have been able to lease in government forests and to manage these forests with a set of rules made by them. Training and extension programs have disseminated knowledge and transferred technologies in the field of vegetable farming, dairy farming, pest control, irrigation management, forest management, poultry, food processing and marketing, cottage industry, tourism, family planning public health, vaccination, cooking and environment.

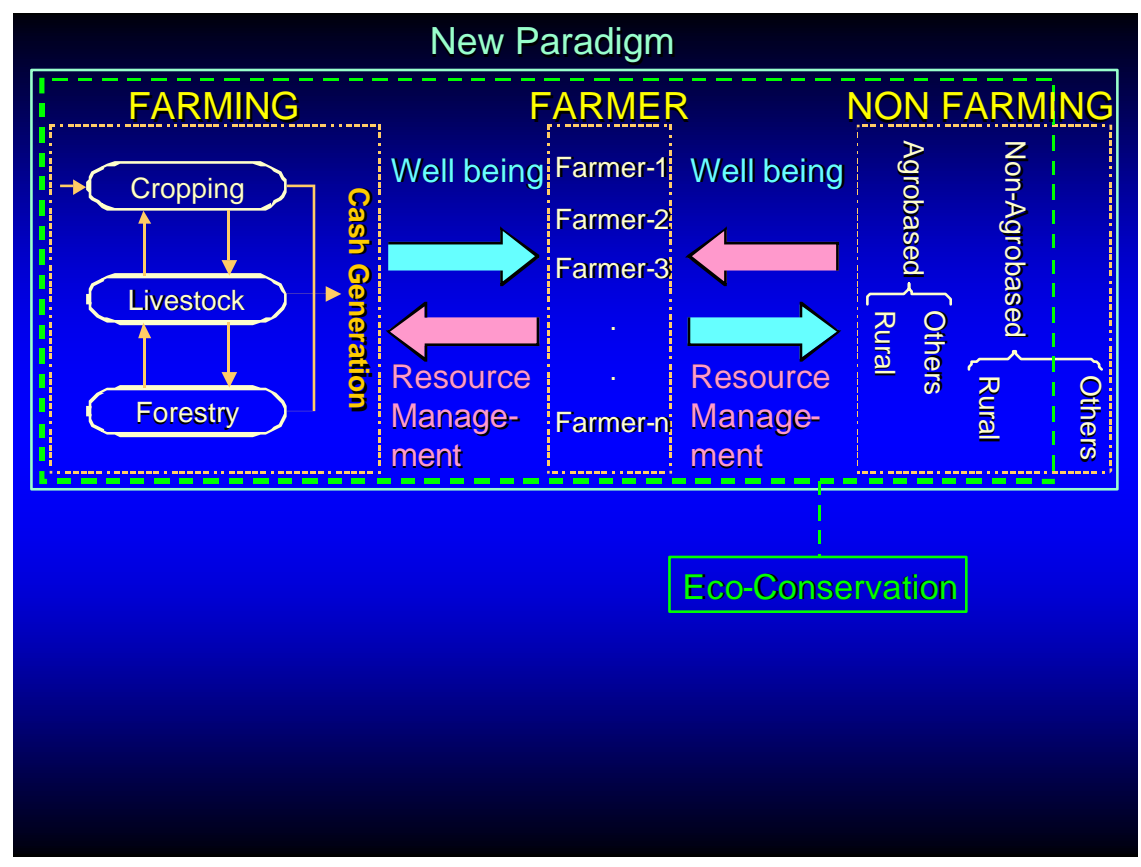

Figure 2: Recent Dynamism in Traditional Farming and Resource Management

Development interventions in many instances have not been able to achieve their stipulated goals. Development interventions are mostly introduced through time-bound projects and rarely continue/expand after completion of project period. This failure seems to be due to deficiency in scientific and technological knowledge about the recommended intervention as well as lack of a 
spirit of mutual aid and spontaneity in people's participation framework provided for dissemination of these interventions. People simply think that development is something that comes from outside, through the whims and fancies of government, international agencies and domestic elites, and something that is imposed on them regardless of their wishes. People are also aware that if they wish to benefit from development programs, they simply have to dance according to the tune of development agencies. The success of community participation is often evaluated in terms of number of people attending meetings called by development agents rather than in terms of whether people have consciously understood and contributed to the program. Repayment of loan soon (often one week) after receipt of the loan is an essential element of all credit programs. Development agencies are more concerned with repayments, rather than trying to understand how the money is being repaid. There are numerous cases of misappropriation of funds. Few privileged people participate repeatedly in various training programs and never actually make use of the know-how gained, whereas many needy and prospective people are left behind. The element of mutual aid, the fundamental aspect of the traditional community participation, is often missing in development interventions. The issues related to forest management drawn from an intensive analysis of a typical village are discussed below.

Forest management - a village level case study

This study village lies in Mahabharat Range in Lalitpur district. Settlements are scattered over 1600-2000 m amsl elevations on steep southern and western slopes. Village communitiy consists of three main ethnic/caste groups: Brahmins (upper Hindu caste people) Magar and Tamang (both Tibeto-Burmans) and Kami (Hindu occupational caste people - cobbler). Forests occupy $56 \%$ of the total village area. Growing stock decreased from $95 \mathrm{~m}^{3} \mathrm{ha}^{-1}$ in $1960 \mathrm{~s}$ to $65 \mathrm{~m}^{3} \mathrm{ha}^{-1}$ in 1980s and again increased to $75 \mathrm{~m}^{3} \mathrm{ha}^{-1}$ in 1997. Presently, there are four Community Forest Users Groups (CFUGs) which manage village forest resources.

After conducting a general survey of the village, $20 \%$ households selected randomly were intensively surveyed to understand the organization and dynamics of farm and forest systems. Questionnaire for Community Forest Users Groups were executed 
followed by participatory rural appraisal (PRA) exercises and discussions with a few key informants.

\section{Forest management before 1990}

After Rana regime (1846-1950) was overthrown, forest resources of Nepal were nationalized through Private Forest Nationalization Act, 1957. The aims of nationalizing the country's forests were to release land from control of a few powerful birta (land granted by the State to people for their meritorious deeds) and to manage forests as national wealth benefiting all citizens equitably (Regmi, 1978). Any extraction needed a formal permission from the District Forest Officer (DFO). Responsibility of forest protection was assigned to forest guards appointed by the government. Villagers, however, viewed the new system as if the government had taken away their age-old forest use rights and disregarded their customary rules/regulations such as talukdari (a local governance system that was abandoned in 1950), kipat (communal ownership of land and forest resources among Tiboto-Burmans) and guthi (land allocated to those who discharge social and religious responsibilities). Due to loss of a sense of ownership and accountability in forest management, villagers started to harvest as much forest goods as possible "illegally". Many a times people negotiated with and took forest guards in confidence before undertaking illicit extractions. The Department of Forest (DoF) with limited capacity was helpless in controlling such widespread acts (Bajracharya, 1982). This turned forests into open access endowment with negligible control over their use. Much of deforestation was observed during this period.

In order to manage the forests properly, the system of Panchayat Forest (PF)/ Panchayat Protected Forest (PPF) was introduced in the year 1978. Management responsibilities of these forests were given to Village Panchayat comprising a few individuals elected by the village community. Reforestation was the main objective of national forest policy. Village Panchayats were authorised to manage forests to meet the local needs only.

Most of the forests of study village were managed under the Kipat, Saraswoti Guthi and Bista Talukdari systems before nationalization of forests. Soon after nationalization, proper rules to control and command forests were not in place. The forest was no 
more "ours" (an understanding that forests belong to people). A few so called village elites, who had courage, were influential, had access to information, plundered forests and converted them to their entitlements. Brahmins in the study village expanded their farm holdings by encroaching forest land. Magars and Tamangs benefited immensely from selling fuelwood and charcoal in the nearby town. Expansion of land holdings by encroaching forest land by Magars and Tamangs was not as marked as that by the Brahimins. The most disadvantaged people were the Kamis who depended on charcoal to sustain their traditional occupation. Village elites asked them to make charcoal from forests by setting fire but did not allow them to cultivate in forest land. Kamis would get charcoal but forest land cleared in the process was taken over by the elites.

Concerned with forest degradation, government emphasized on raising tree plantations in and around villages. Tree saplings were provided free of cost to villagers and schools. Brahmins and Magars benefited most by planting saplings in their new endowments of private lands, partly because nursery was very close to their dwellings. Kamis usually living at the periphery of the village did not benefit much. Kamis have much less private forest compared to other ethnic/ caste people and consequently are more dependent on community forests $(87 \%)$ (Table 1).

Table 1. Relative dependence of different ethnic/caste groups on private and community forests.

\begin{tabular}{lcc}
\hline Ethnic/Caste group & Private Forest (\%) & Community Forest (\%) \\
\hline Brahmin & 43 & 51 \\
Magar & 31 & 69 \\
Tamang & 30 & 63 \\
Kami & 9 & 87 \\
\hline
\end{tabular}

Source: Field survey, 2000.

\section{Forest management during late 1990s}

As per Forest Sector Master Plan 1988, Forest Act 1993 and Forest Rule 1995, forests have been classified as private and state owned forests. State Forests are divided into Community Forests 
and National Forests managed by local communities and Department of Forest and Soil Conservation, respectively. National Parks are under Department of National Park and Wildlife Conservation and Guthi Forests under Guthi Corporation. Villagers have started to participate in forest management more deeply, by forming forest users group. Each users group has a working committee consisting of 7-11 memebers. The users groups manage Community Forests and utilize resources according to an operation plan drawn by them and approved by the Divisional Forest Officer. A given CFUG discusses its operational plan with the village development committee and other CFUGs so as to overcome problems in identification of users, sharing of benefits, participation and leadership and deciding the $\mathrm{CF}$ boundaries. This institution can sell the resources and get economic benefit that can be used in forest and community development work free of any government interventions. As of 2002, there are about 12,600 CFUGs in the country, managing about one million ha of forest with involvement of one and half million people in management. This has been achieved in spite of constraints in forming of CFUG, sharing of benefits, participation, leadership and deciding the $\mathrm{CF}$ boundaries more so in non homogeneous communities where interests of different ethnic/caste groups clash.

There are 4 CFUGs in the study village which manage 247 ha of forest with involvement of 186 households. All villagers with household as an operational unit, become members of the CFUG in the ward spontaneously. The members equally contribute voluntary labor in guarding forests with the core concept of mutual aid. A managing committee with 11 members is formed to look after the day-to-day matters and represents the group in negotiations with the Divisional Forest Officer and village committee. The managing committee members are selected by the group members from themselves on the basis of quality, contribution and trustworthy merits of individuals constituting the group. The group members can collect dried fallen leaves, branches and twigs everyday as per their need for fuelwood, two bharis (one bhari $=30 \mathrm{~kg}$ ) of green fodder per day per household, and specified quantity and quality of timber for construction or repair of houses, occasionally as decided by the managing committee. Once permitted a member has to fell tree on his/her own responsibility and pay the revenue of NR 5 per $\mathrm{ft} 3$ (US \$ 
Community participation in Nepal 201

$1=$ NR 70) to the group. Non-timber forest products, i.e, herbs, ornamental flowers, resins, raw materials for paper and handicrafts, fruits, mushrooms and other edibles, and medically valued goods are collected once in a while and shared among group members. At times, when extractions are large enough, they are sold under the supervision of the managing committee.

Some problems faced in the study village are: (a) exclusion of some households in the CFUG due to their "low" caste status or political affiliation, (b) conflict in interest of forest goods use - Kamis and big households demanding to collect more fuelwood, those with more cattle demanding for more fodder and more affluent families demanding for more timber, (c) inability to volunteer labor equally by different users, (d) fierce competition in electing group leader, and (e) differing opinions on boundaries of customarily used forests. These issues subtly affect forest management and consequently the well being of the villagers. More than $90 \%$ households in the study village have taken loan from institutions, such as, Small Farmers Development Programs of Agricultural Development Bank, Small Crafts Industry and Rural Development Program of Nepal Bank Limited, local saving and credit groups and village lenders. More than half of the loan amount is used for purchasing cows and buffaloes for dairy farming. Under the Livestock Development Program, two milk collection centers have been established in the village.

\section{Resource management and well being of the people}

Before 1990 forests belonged to the government and villagers had to make formal or informal negotiations with officials for using any forest product. The quantity of timber (12 ft3 per year per household) permissible to a family was too low to satisfy essential needs (Table 2). Average permissible annual harvest of fuel wood per household was 216 bhari, but Tamangs and Kamis were granted a relatively larger level of fuelwood removals. Yet, villagers were unable to collect the needed quantity of fuelwood and hence burnt dung cakes.

Fodder was harvested at an average rate of 183 bhari per household per year. Ethnic/caste groups differed in term of size of livestock holdings. About 3.4 hours a day were spent on collecting fuelwood and 2.4 hours collecting fodder (Table 3). Of 780 liters 
202 Maharjan

milk produced by average household, 130 liters were consumed and 650 liters were sold (Table 4). Animals seemed under-nourished and houses were of poor quality indicating shortage of forest resources.

Table 2. Annual entitlement of forest products per household in the years 1990 and 2000.

\begin{tabular}{|c|c|c|c|c|c|c|}
\hline \multirow{2}{*}{$\begin{array}{l}\text { Ethnic/ } \\
\text { Caste group }\end{array}$} & \multicolumn{3}{|c|}{1990} & \multicolumn{3}{|c|}{2000} \\
\hline & $\begin{array}{l}\text { Fuelwood } \\
\text { (bhari) }\end{array}$ & $\begin{array}{l}\begin{array}{l}\text { Fodder } \\
\text { (bhari) }\end{array} \\
\end{array}$ & $\begin{array}{l}\text { Timber } \\
\left(\mathbf{f t}^{3}\right)\end{array}$ & $\begin{array}{l}\text { Fuelwood } \\
\text { (bhari) }\end{array}$ & $\begin{array}{l}\text { Fodder } \\
\text { (bhari) }\end{array}$ & $\begin{array}{r}i m b e r \\
\left(\mathrm{ft}^{3}\right)\end{array}$ \\
\hline Brahmin & 198 & 153 & 11 & 276 & 209 & 49 \\
\hline Magar & 181 & 263 & 10 & 249 & 291 & 30 \\
\hline Tamang & 252 & 186 & 15 & 248 & 195 & 27 \\
\hline Kami & 234 & 137 & 11 & 258 & 139 & 16 \\
\hline Average & 216 & 183 & 12 & 258 & 220 & 31 \\
\hline
\end{tabular}

Source: Field survey, 2000 and USC-Canada Baseline Survey, 1990; One bhari is equal to $30 \mathrm{~kg}$.

Villagers, regardless of the ethnicity and caste, were entitled for large quantities of fuelwood, fodder and timber in 2000 than a decade ago (Table 2). All these entitlements were systematic, legal and within the prevailing endowments. People were getting larger quantities of forest products with same amount of labor and time spent in collection (Table 3). The average harvest of timber has increased by more than 250\% during 1990-2000 period following simplification of felling procedures. The magnitude of increase in case of Kamis was less compared to the other ethnic/caste groups. This difference between Kamis and other ethnic/caste groups was due to the difference in their tree capital before 1990.

Livestock holdings have increased in all ethnic/caste groups during 1990-2000 period following support from Small Farmer Development Program and Livestock Development Program. There has been significant increase in milk production per household as well as in livestock productivity (Table 4). People have benefited by consuming greater quantities of milk as well as by increasing income from the sale of milk and milk products. 
Community participation in Nepal 203

Table 3. Time spent (daily) by an average household (ethnic group/ caste wise) for collection of fuelwood and fodder in the years 1990 and 2000.

\begin{tabular}{llllllll}
\hline \multirow{2}{*}{$\begin{array}{l}\text { Ethnic/ } \\
\text { Caste group }\end{array}$} & \multicolumn{3}{c}{$\mathbf{1 9 9 0}$} & & \multicolumn{3}{c}{ 2000 } \\
\cline { 2 - 3 } \cline { 6 - 7 } & $\begin{array}{l}\text { Fuelwood Fodder } \\
\text { (hours) }\end{array}$ & $\begin{array}{c}\text { Thours) } \\
\text { (hourser }\end{array}$ & & $\begin{array}{l}\text { Fuelwood } \\
\text { (hours) }\end{array}$ & $\begin{array}{l}\text { Fodder } \\
\text { (hours) }\end{array}$ & $\begin{array}{c}\text { Timber } \\
\text { (hours) }\end{array}$ \\
\hline Brahmin & 3.4 & 2.5 & 5.9 & & 3.1 & 2.2 & 5.3 \\
Magar & 3.1 & 2.6 & 5.7 & & 2.7 & 2.2 & 4.9 \\
Tamang & 3.8 & 2.5 & 6.3 & & 2.9 & 2.0 & 4.9 \\
Kami & 3.3 & 1.5 & 4.8 & & 2.8 & 1.1 & 3.9 \\
\hline Average & 3.4 & 2.4 & 5.8 & & 3.0 & 2.0 & 5.0 \\
\hline
\end{tabular}

Source: Field survey, 2000 and USC-Canada Baseline Survey, 1990

Table 4. Animal holding, annual milk produced and sold per household in the years 1990 and 2000.

\begin{tabular}{|c|c|c|c|c|c|c|}
\hline \multirow{2}{*}{$\begin{array}{l}\text { Ethnic/ } \\
\text { Caste group }\end{array}$} & \multicolumn{3}{|c|}{1990} & \multicolumn{3}{|c|}{2000} \\
\hline & $\begin{array}{l}\text { Animals } \\
\text { (no.) }\end{array}$ & $\begin{array}{l}\text { Milk } \\
\text { produced } \\
\text { (l) }\end{array}$ & $\begin{array}{l}\text { Milk sold } \\
\text { (l) }\end{array}$ & $\begin{array}{l}\text { Animals } \\
\text { (no.) }\end{array}$ & $\begin{array}{l}\text { Milk } \\
\text { produced } \\
\text { (l) }\end{array}$ & $\begin{array}{l}\text { Milk sold } \\
\text { (l) }\end{array}$ \\
\hline Brahmin & 2.1 & 940 & 786 & 2.8 & 1841 & 1534 \\
\hline Magar & 2 & 751 & 626 & 2.6 & 1686 & 1405 \\
\hline Tamang & 1.9 & 790 & 658 & 2.3 & 1313 & 1250 \\
\hline Kami & 1.2 & 900 & 750 & 3.1 & 1572 & 1310 \\
\hline Average & 1.8 & 780 & 650 & 2.6 & 1631 & 1359 \\
\hline
\end{tabular}

Source: Field survey, 2000 and USC-Canada Baseline Survey, 1990. Note: Animals include cow and buffalo

Restrictions on traditional community participation and weak institutional settings during 1957-1990 period seem to have encouraged unsustainable ways of forest resource uses in Nepal. As villagers were always dictated by authorities and were not allowed to manage the forests, they were unable to think of future problems likely from over-exploitation of forest resources. In such a situation socially stronger sections viz., Brahmins, Magars and Tamangs took more benefit by expanding farming in forest land and also by getting 
more grants for reforestation provided by the government. The socially backward Kamis could not benefit much due to their traditional occupation, distant dwellings and poorly educated children.

With handing over of forest management to users groups in 1990, community participation in forest management started regaining its importance. Villagers internalized development interventions in their own operational plans that gave due consideration to both present and future cocerns. In the new institutional set-up, villagers assumed the roles of planners, implementers and beneficiaries simultaneously. By building on community traditions and social norms, people could harvest enough fuelwood and abandoned the practice of burning dung cakes. They could harvest required fodder by spending just two hours a day. They could also harvest more timber and improve their housing, although the Kamis lagged behind other ethnic/caste groups. All these increased entitlements and enhancement of well being of the people were achieved with the simultaneous increase in forest growing stock and crown cover.

\section{Conclusions}

Development interventions should not merely provide exogenous impetus, but should be implemented such that they get internalized as a component of people's programs. The first essential condition in community participation for internalizing any development intervention is spontaneity: spontaneity in forming groups, in feeling the need of credit, technology, knowledge and other information, and spontaneity in acknowledging the necessity of savings. The second condition required for effective community participation is to retain mutual aid as the core concept among the members of CSOs and give due consideration to traditional values and social norms. A sense of joint ownership as well as accountability among members of a group, leaders and leads, is extremely important from the point of sustainable management of natural resources.

Development agencies should be willing to adapt to the community systems or even adopt them depending their strengths and circumstances. Development programs should be flexible so as to take into consideration the location specificities.

Two broad types of community development programs may be conceived: general and ad-hoc. General programs are mostly social 
in nature and have a long term perspective. They would cover all traditional organizations, such as, guthi, dhikur, mana-pathi, as well conventional institutions such as cooperatives, associations and users groups. Ad-hoc type programs will be problem specific and will have a short term perspective. It will emerge in response to the need conceived by the people and will end after the problem is solved. Tackling calamities and encountering wild animals, pests, poachers, sneakers and epidemics are some of the issues that are generally dealt by ad-hoc community programs (Figure 3 ).

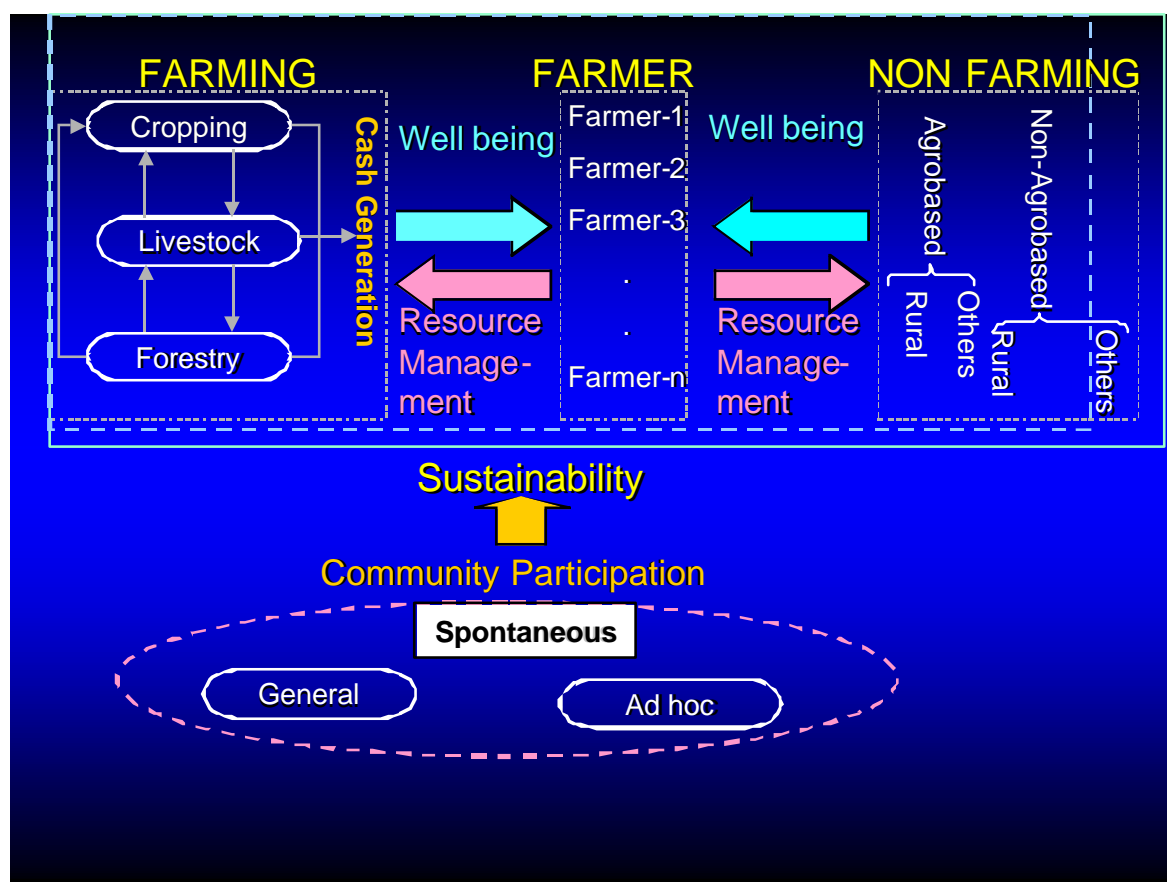

Figure 3: Desired Dynamism in Farming and Spontaneous Community Participation in Resource Management

\section{References}

Agricultural Development Bank. 1984. Highlights on Small Farmer Development Programme in Nepal. Institutional Division, Head Office, Kathmandu.

Bajracharya, D. 1983. Fuel, food or forest? Dilemmas in a Nepali 
village. World Development 11: 1057-1074.

Bartlett, A.G. and Malla, Y.B. 1992. Local forest management and forest policy in Nepal. Journal of World Forest Resource Management 6: 99-116.

Basnyat, B.B. 1995. Nepal's Agriculture Sustainability and Intervention: Looking for New Directions. Cip-Data Konkinklijke Biblotheek, Den Haag.

Bongartz, H. and Dahal, D.R. 1996. Development Studies. Self-help Organizations, NGOs and Civil Society. Nepal Foundation for Advanced Studies for Friedrich Ebert Stiftung, Kathmandu.

Dahal, D.R. and Guru-Gharana, K.K. (Eds.). 1996. Development Strategy for Nepal. Nepal Foundation for Advanced Studies, Kathmandu.

Dahal, D.R. 1983. Economic development through indigenous means. Contributions to Nepalese Studies 11: 1-20.

Domroes, M. (Ed.). 2003. Translating Development: The Case of Nepal. Social Science Press, New Delhi.

Rigg, D. 1993. The World Food Problem. Blackwell Publishers, London.

Department of Forest. 1995. Community Forest Directive. HMG Ministry of Forest and Soil Conservation, Kathmandu, Nepal.

Department of Forest. 1996. "Ban Ain 2049 Tatha Ban Niyamabali 2051" [Forest Act 1993 and Forest Rule 1995]. HMG Forest Development Project, HMG Ministry of Forest and Soil Conservation, Kathmandu, Nepal, (in Nepali).

Ishii, H. 1980. Recent economic changes in Newar village. Contributions to Nepalese Studies 8: 157-179.

Ishii, H. 1987. Social change in a Newar village. In: Gutschow, N. and Michaels, A. (Eds.) Heritage of the Kathmandu Valley. VGH Wissenschaftsverlag, Sankt Augustin, pp. 335-353.

Ishii, H. 1991. Agricultural labour recruitment and the caste system - A perspective from Newar, Parbate hindu and Maithili society. The Japanese Journal of Ethnology 56: 131-158 (in Japanese).

Rajendra, K.C. 2000. Development Management of NGO. Reda Nepal, Kathmandu (in Nepali).

Leach, M., Mearns, R. and Scoones, I. 1999. Environmental 
Community participation in Nepal 207

entitlements: Dynamics and institutions in community-based natural resource management. World Development 27: 225247.

Maharjan, K.L. 1995. "Nogyo no Kozoteki Teitai to Kaihatsu Seisaku" [Structural stagnation of agriculture and development policy of Nepal]. In: Kawai, A. (Ed.) "Hatten Tojokoku Sangyo Kaihatsu Ron” [Industry Development of Developing Countries in South Asia], Hoso Daigaku Kyoiku Shinkokai, pp. 118-138 (in Japanese).

Maharjan, K.L. 1997. Impacts of Irrigation and Drainage Schemes on Rural Economic Activities in Bangladesh. Research Center for Regional Geography, Hiroshima University, Japan.

Maskey, B.K. 2000a. Development Governance: Agenda for Action. Centre for Development and Governance, Kathmandu.

Maskey, B.K. 2000b. Non-governmental Organizations. I. Development: Search for a New Vision. Centre for Development and Governance, Kathmandu.

Niroula, C.B. 1997. Case Study in Land Use Change in Lele Watershed Area in Lalitpur District by Applying GIS. Unpublished Dissertation, Tribhuvan University, Kathmandu, Nepal.

Panday, D.R. 1990. Nepal's Failed Development: Reflections on the Mission and the Maladies. Nepal South Asia Centre, Kathmandu.

Paudyal, D.P. 1994. Strategies for Local Level Planned Development in Nepal: An Evaluation of the Decentralization Act 1982 From the Local Perspective. Prabesh \& Pratik, Kathmandu.

Regmi, M.C. 1978. Land Tenure and Taxation in Nepal. Ratna Pustak Bhandar, Kathmandu.

Sen, A. 1981. Poverty and Famines: An Assay on Entitlement and Deprivation. Clarendon Press, Oxford.

Shrestha, S.K. 1992. Baseline Survey Report of Gusel \& Dal Choki VCDs, Lalitpur. Man-Tech. Consult, Kathmandu, Nepal.

Slater, R. 1991. From Farm to Firm: Rural Diversification in the Asian Countryside. Avebury Academic Publishing Group, England. 